\title{
Effect of culture on perceptions of IS service quality
}

\author{
Ahmad A. Rabaa'i* \\ Department of Computer Science and Information Systems, \\ College of Arts and Sciences, \\ American University of Kuwait, \\ Safat, Kuwait \\ Email: arabaai@auk.edu.kw \\ *Corresponding author

\section{John G. Gammack}

College of Technological Innovation, Zayed University, Abu Dhabi, UAE

Email: john.gammack@zu.ac.ae

\begin{abstract}
Although providing Information Service Functions (ISFs) is common to organisations in all cultures, how the quality of these services is perceived in different cultures is poorly understood. Culture is complex and the broad values that characterise a particular culture are known to affect technology implementation and adoption. Service quality is also multidimensional, and various aspects may be prioritised differently by cultures with different value systems, with implications for management. This study examines how ISF's service quality dimensions are perceived in Jordan and Australia, which have contrasting profiles on Hofstede's typology of cultures. We hypothesise and test the influences of salient cultural characteristics using the four-dimensional 'Zones of Tolerance' (ZOT) service quality measure of Kettinger and Lee to compare demographically similar users' service quality perceptions. The results indicate that, associated with their cultural characteristics, users' perceptions vary on each of the four dimensions of ZOT service quality.
\end{abstract}

Keywords: cultural dimensions; Jordan; Australia; information services function; zones of tolerance; service quality; SERVPREF.

Reference to this paper should be made as follows: Rabaa'i, A.A. and Gammack, J.G. (2014) 'Effect of culture on perceptions of IS service quality', Int. J. Intercultural Information Management, Vol. 4, No. 1, pp.15-33.

Biographical notes: After graduating from Queensland University of Technology (QUT) with a PhD in Information Systems, Ahmad A. Rabaa'i took a Research Fellow position within the IT Evaluation Program at QUT. After 18 months, he took his present appointment as an Assistant Professor of Information Systems at the American University of Kuwait (AUK).

After graduating from Cambridge with a $\mathrm{PhD}$ in knowledge acquisition John G. Gammack took postdoctoral positions at Bristol Business School then Bristol Transputer Centre researching and developing intelligent systems. Following work at the University of the West of Scotland he took a professorial appointment as Head of IT at Murdoch University, then became the professor and head of information systems at Griffith University, Australia. After three 
years teaching and developing courses and faculty in China he took his present appointment as Professor in Enterprise Systems at Zayed University, UAE. He is co-author of The Book of Informatics and has around 200 publications to date.

\section{Introduction}

The predominant organisational unit to provide end-user support is the Information Services Function (ISF). The ISF is "an integral part of achieving organizational success" (and may be defined as) "all IS groups and departments within the organization" (Chang and King, 2005, p.86). Whether distributed or centralised, the ISF is expected to provide various support services to end-users in a cost- and time-effective manner, across a variety of different packages and configurations, covering issues such as data backup and recovery, hardware and software maintenance, upgrades and installation (Jiang et al., 2002; Shaw et al., 2002). Assessing ISF's performance has long been an important issue to IS executives (Carlson and McNurlin, 1992; Saunders and Jones, 1992) that has remained prominent in IS studies (e.g. Chang and King, 2005; Munkvold, 2003; Pitt et al., 1997; Saunders and Jones, 1992; Shaw et al., 2002; Velsen et al., 2007). Poor performance of the ISF is a serious inhibitor to good business performance (Carlson and McNurlin, 1992; Chang and King, 2005, p: 86), and so more recent studies have focused on conceptualising and measuring service quality.

The role of the ISF has changed increasingly from being originally a manufacturing activity, involving development and operation of large-scale hardware and software systems (Zmud, 1984), to include additional roles of distribution and technology transfer that require higher levels of user interaction and service delivery. Recognising the changed emphasis towards service functions, several IS researchers (e.g. Jiang et al., 2002; Kettinger and Lee, 1994; Kettinger and Lee, 2005; Shaw et al., 2002; Watson et al., 1998) adapted the Service Quality (SERVQUAL) measure (developed in the marketing field) to evaluate the quality of the services provided by the ISF. IS quality became defined as "The quality of the support that system users receive from the IS department and IT support personnel. For example: responsiveness, accuracy, reliability, technical competence, and empathy of the personnel staff" (Petter et al., 2008, p.239).

While ISF's service quality has received considerable attention in a body of work spanning more than two decades, we identify two major limitations. Firstly SERVQUAL is not now considered to be the most suitable instrument for measuring ISF, and secondly the work to date has primarily been done in a Western-centric cultural context. Although cross-cultural research around ISF's service quality is not yet very mature, if ISF's service quality dimensions vary from one culture to another, this may provide useful insights and managerial implications for how organisations should deal with different cultural groups.

This study proceeds from a central interest in the importance of understanding cultural influences on ISF's service quality. The study examines perceptions of ISF's service quality in two countries (Australia and Jordan) and aims to address the main research question: "What are the influences of different cultural values on perceptions of ISF's service quality?" After critical consideration, we adopt Hofstede's typology of 
cultures and the 'Zones of Tolerance' (ZOT) service quality measure (Kettinger and Lee, 2005). We also use Leung and Bond's (1989) technique for cross-cultural comparisons.

The remainder of the paper is organised as follows. First, we review relevant literature before presenting Hofstede's typology of culture and the research hypotheses in Section 3. Section 4 addresses the research approach and methodology. The research findings are presented in Section 5. Finally, the paper concludes with a summary, implications and limitations in Section 6.

\section{Review of relevant literature}

\subsection{The Service Quality (SERVQUAL) ${ }^{1}$ instrument}

Parasuraman et al. (1988) define 'service quality' broadly as "a global overarching judgment or attitude relating to the overall excellence or superiority of a service". Their service quality (SERVQUAL) instrument was originally developed in the marketing field, and this 22-item measure has been dominant in the services marketing discipline for several decades. The SERVQUAL instrument was developed as a way to measure the gaps between a consumers' expected and perceived level of service quality. The gap is measured across five dimensions presented in Table 1, which represent the refined and stabilised version of the original instrument.

Table 1 The five dimensions of SERVQUAL

\begin{tabular}{ll}
\hline Dimension & Explanation \\
\hline Tangibles & Physical facilities, equipment and appearance of personnel \\
\hline Reliability & Ability to perform the promised service dependably and accurately \\
\hline Responsiveness & Willingness to help customers and provide prompt service \\
\hline Assurance & $\begin{array}{l}\text { Knowledge and courtesy of employees and their ability to inspire trust and } \\
\text { confidence }\end{array}$ \\
\hline Empathy & Caring, individualised attention the firm provides its customers \\
\hline
\end{tabular}

Source: Adapted from Parasuraman et al. (1988)

SERVQUAL is administered as two questionnaires (i.e. one capturing expectations and one capturing perceptions). The first part, consisting of 22 questions for measuring expectations, is benchmarked in terms of the performance of an excellent provider of the service being studied. The second part, also consisting of 22 questions, measures perceptions by framing questions in terms of the performance of the actual service provider. Service quality for each dimension is captured by a gap score $(G)$, where $G$ is the difference between corresponding perception of delivered service $(P)$ and expectation of service $(E)$ for each dimension $(G=P-E)$.

\subsection{The SERVQUAL instrument and IS service quality}

Kettinger and Lee (1994) established a short-form (13 items) SERVQUAL, within the ISF context. This had strong validity for four of the Parasuraman et al. (1991) SERVQUAL dimensions, but reserved claims of external validity because their study was a single sample test. 
Pitt et al. (1995) independently analysed SERVQUAL data from three different sample sites using principal components and maximum likelihood methods, deriving a three-, five- and seven-factor solutions. Given their findings, Pitt et al. (1995, p.181) report that "SERVQUAL does not clearly delineate among the dimensions of service quality". They warn users of the 22-item SERVQUAL to be aware of the co-alignment of the dimensions of responsiveness, assurance and empathy due to the semantic similarity of these concepts and indicate that the reliability of the tangible dimension is low. Buttle (1996) gives an extended critique noting and considering several important theoretical and operational limitations that call its validity into serious question. Within ISF, the use of SERVQUAL has also been the subject of considerable debate (Fisk et al., 1993; Kettinger and Lee, 1994; Parasuraman et al., 1993; Pitt et al., 1997; Van Dyke et al., 1997; Van Dyke et al., 1999). The focus of these papers was mainly concerned with calculating the differences between the two service quality constructs, namely expectations and perceptions.

IS researchers have also expanded the use of service quality into new areas, such as measuring service quality longitudinally (Watson et al., 1998) and internationally (Kettinger et al., 1995). More recently, IS researchers have also adapted service quality for use in the evaluation of electronic service environments such as e-commerce websites (e.g. Li et al., 2003; Wang and Tang, 2003) and internet banking sites (Jayawardhena, 2004).

Boredom and confusion with repeating a 22-item questionnaire was one operational problem noted by Buttle (1996), and SERVPREF was derived by Cronin and Taylor (1992) as a single measure based on perceptions, and eschewing the gap calculations. Jain and Gupta's (2004) results are clear that SERVPREF is superior: they recommend that it be employed for assessing overall service quality and when making service quality comparisons. For management interventions, SERVQUAL, however, remains better diagnostically. In an attempt to resolve this, a meta-analysis study, covering 17 years and five continents, was done by Carrillat et al. (2007); however, because all studies done outside the USA had used adapted scales, the issue cannot yet be resolved using a metaanalysis approach, further motivating the need for cross-cultural research and comparable instrumentation.

In information systems, Kettinger and Lee (1997) conducted an empirical comparison between SERVQUAL and SERVPERF in terms of the psychometric superiority in the IS setting. That is, while slightly better reliability and explained variance were noticed with the SERVPERF measure, neither SERVQUAL nor SERVPERF data fit well enough to hold a model of the proposed five-factor structure. Nonetheless, measuring IS service quality has been praised for its practical relevance (Jiang et al., 2002; Kettinger and Lee, 2005), and SERVQUAL variants continue to be used to evaluate technical support service interactions (e.g. Carr, 2002).

Kettinger and Lee (2005) reported on a study of an alternative instrument adapted from marketing referred to as the ZOT service quality measure. The authors argued that this ZOT measure is conceptualised to overcome one of the most significant points of criticism with the original SERVQUAL instrument, namely the need for a more parsimonious conceptualisation of service quality expectations, while retaining 
the practical diagnostic power of understanding service expectation levels. IS ZOT SERVQUAL contains measures for desired, adequate and perceived service quality levels, and identified 18 commonly applicable question items.

Using commonly accepted factor selection criteria, four constructs with 18 items were derived. Three original SERVQUAL constructs emerged from the exploratory factor analysis (tangibles, reliability and responsiveness). However, two of the original dimensions, empathy and assurance, were merged into one dimension. Kettinger and Lee (2005, p.612) argued that, based on a review of the retained items and the seeming similarity of the constructs when applied in the IS context, "the new merged construct was named rapport because the construct items focus on an IS service provider's ability to convey a rapport of knowledgeable, caring, and courteous support". This is consistent with the historical refinements of the instrument, where correlated dimensions collapse into a general construct. The resulting new four dimensions of IS ZOT SERVQUAL are presented in Table 2.

Table 2 The four dimensions of IS ZOT SERVQUAL

\begin{tabular}{ll}
\hline Dimension & Explanation \\
\hline Reliability & The ability to perform promised ISF services dependably and accurately \\
\hline Responsiveness & The willingness to help ISF users and to provide prompt service. \\
\hline Rapport & $\begin{array}{l}\text { The ISF ability to convey a rapport of knowledgeable, caring, and courteous } \\
\text { support }\end{array}$ \\
\hline Tangibles & Physical facilities, equipment, and appearance of personnel \\
\hline
\end{tabular}

Source: Adapted from Kettinger and Lee (2005)

The IS ZOT SERVQUAL instrument was pretested through a series of interviews with IS professionals and IS graduate students. After pretesting and refining the instrument, two samples were chosen for the cross-validation: an initial sample from the university setting and a holdout sample from the industry setting. The findings represent an important step towards addressing past concerns with the original IS SERVQUAL's expectation measure and gap-scoring. The IS ZOT SERVQUAL instrument has strong practical potential as a diagnostic tool through which managers can quickly visualise their current IS service quality situation and design corrective actions. This was therefore the instrument on which we based this study.

\subsection{The link between the culture and IS service quality}

The theoretical relation between culture and information technology in general is long established. Various IS researchers have studied this relationship for over two decades, and in many areas have found cultural influences directly affecting the implementation and adoption of specific technologies and information systems. For example, Ho et al. (1989) found cultural differences in the use of Group Decision Support Systems (GDSS); Robey and Rodriquez-Diaz (1989) identified cultural differences that affected IS implementation success and Nelson et al. (1992) found end-user computing profoundly different in the USA compared to Japan. King and Sethi (1993) reported that globally run firms often operate differing ISF operations in varying countries, and integration of these culturally diverse systems "requires substantial understanding of local business practice 
and people” (p.581). More recently, Rabaa'i (2009) investigated the impact of culture on Enterprise Systems (ES) implementations and found again that, for at least one Arab country, the cultural factors determined the success or otherwise of the implementation.

While the relation between culture and IT is not new, the specific impact of culture on IS service quality is not yet widely understood. In fields such as marketing and banking, a great body of literature relates culture and service quality, both within and between cultures (e.g. Edvardsson and Gustavsson, 1988; Malhotra et al., 1994; Mattila, 1990). Within the Jordanian culture, customers of Jordanian commercial banks rated the level of service quality positively, with means $(\max =5)$ for responsiveness and reliability of 3.91 and 3.9, respectively (Mohammad and Alhamadani, 2011). In the UAE, reliability was prominent when two Islamic banks were compared using an adaptation of SERVQUAL (Al-Tamimi and Al-Amiri, 2003), but Mohammad and Alhamadani (2011) criticised this study for making no attempt to address new service quality dimensions either particular to or related to the UAE culture. Redressing this, Jabnoun and Khalifa (2005) proposed a culturally specific measure of service quality for the UAE, arguing that such customised service quality measures are crucial both for MNCs and for customer attraction and retention within a culture.

In his cross-cultural comparative study of supermarket services, Espinoza (1999) found Quebecers (residents of the Canadian province of Quebec) prioritised responsiveness, whilst Peruvians valued tangibles more. Using SERVQUAL instrument, Donthu and Yoo (1998) compared the effect of cultural orientation on (banking) service quality expectations, for groups from the USA, Canada, the UK and India. They found that, as a result of their cultural orientation, service quality expectations indeed varied across cultures, both overall and for the different individual dimensions of service quality.

Kettinger et al. (1995) examined the perceptions of ISF service quality in four countries (Hong Kong, Korea, the Netherlands and the USA), by using a measure of service quality reported by Kettinger and Lee (1994). Based on confirmatory factor analysis, support was found for four of the original five SERVQUAL quality dimensions in the USA and the Netherlands. However, the same four-dimensional measurement model did not fit the Hong Kong and Korean samples. The authors argued that the Hong Kong and Korean samples shared a somewhat similar factor structure that differs from the shared USA and Netherlands structure. Their findings support previous research that has found an 'Asian factor' with differing definitions of IS service quality. They stated that their findings suggest that the feasibility of standardised global ISF measurement depends heavily on the relative magnitude of cultural effects. Apart from the Kettinger et al. (1995) study, few (if any) studies have directly investigated the relationship between culture and IS service quality. Moreover, to the best of our knowledge, none of the Arab world countries have been investigated in this regard.

\section{Typologies of culture and the research hypotheses}

Defining culture has long been problematic: a seminal analysis of the concept identified 164 definitions (Kroeber and Kluckhohn, 1952), indicating the complexity and dimensionality of the construct. Several typologies of culture exist, broadly aiming to simplify the variation along major differentiating factors and dominant values. For example, with a definitional focus on emotion, a society may variously emphasise guilt (individual, internal) or shame (social, external) in sanctioning behaviour (Benedict, 
1946), or, emphasising communication of meaning, be predominantly 'high context' (implicit, unstated) or low context (explicit, direct) (Hall, 1976). Other typologies emphasise differences in conceptual constructions such as time, status or emotional expressivity (Trompenaars and Hampden-Turner, 1997) or whether the self is primarily construed as independent or interdependent (Markus and Kitayama, 1991). Probably the most generally influential, however, is the typology of Hofstede (1980) who, defining culture as the "collective programming of the mind which distinguishes the members of one group or category of people from those of another" (Hofstede, 1994, p.4), established four well-validated dimensions of national culture. Described in more detail below, these are Power Distance (PDI), Individualism (IDV), Masculinity (MAS) and Uncertainty Avoidance (UAV), to which a fifth, Long-Term Orientation (LTO) was added subsequently (Hofstede, 1991). ${ }^{2}$ While the four dimensions initially were developed from employees of just one international firm, IBM, they have been found to be generalisable and "(show) meaningful relationships with important demographic, geographic, economic and political indicators of a society" (Kale and Barnes, 1992, cited in Donthu and Yoo, 1998). ${ }^{3}$

Specific typologies of cultures are variously criticised on grounds such stereotyping, implicit assumptions of cultural superiority, ignoring important subcultures or dilution of relevance through globalisation and dominating internet communities, but they remain important in guiding and interpreting cross-cultural research by identifying relatively dominant values. The cultural dimensions of Hofstede embody salient differentiating values across cultures, but have been specifically criticised for reasons including (1) the internal validity of the dimensions and (2) the method of constructing the scales. While such criticisms may seem reasonable, there has been considerable empirical verification over 40 years, and Hofstede's cultural dimensions have other appealing attributes, such as the size of the original sample $(116,000)$ and the codification of cultural traits along numerical indices. Controlling for the effects of organisational culture by sampling only within IBM, Hofstede's typology is also the most widely used among international marketing and management scholars, and was therefore chosen for the present study. Donthu and Yoo (1998) also used Hofstede's typology but note that, though often used as a surrogate, a country is not the same as a culture (arguably, the USA and Canada are a single culture which embraces very different subcultures: Black, Hispanic, Native American ...). It is an ecological fallacy to infer an individual property from a group characteristic, and Yoo et al. (2011) have proposed that alternative approaches that avoid this issue be used. In the present study, therefore, to apply the instrument validly to data from individuals, Leung and Bond's (1989) technique is used, as described in the next section, after we introduce the essential characteristics of Hofstede's typology.

Power distance (PDI) is defined as "the extent to which the less powerful members of institutions and organizations within a country expect and accept the power is distributed unequally" (Hofstede, 1991, p.27). Power distance also reflects general human inequality in areas such as wealth, power, prestige and law. People of high power distance show great reliance on centralisation and formalisation of authority and great tolerance for the lack of autonomy, which fosters inequalities in power and wealth (Hofstede, 1980). Also, people of high power distance show tolerance in accepting power hierarchy, tight control, vertical top-down communication and even discrimination by age, gender, educational level, race and family background. In cultures with a high power distance, users would respect the service provided by the ISF and think that the ISF's services are beyond their grasp. As a result of their tolerance in accepting inequalities in power, they are likely to 
set a low level of service quality perceptions. Moreover, such users would not perceive high-performance services even though they may think the ISF know and work better than they do themselves. Thus:

Hypothesis 1a: High power distance users have low ISF's service quality perceptions.

Hypothesis 1b: Low power distance users have high ISF's service quality perceptions.

Uncertainty avoidance (UAV) is defined as "the extent to which the members of a culture feel threatened by uncertain or unknown situations" (Hofstede, 1991, p.113). Uncertainty avoidance reflects the level of tolerance for uncertainties and ambiguities embedded in everyday life (Hofstede, 1980). People of low uncertainty avoidance tend to accept uncertainty without much discomfort, take risks easily and show tolerance for opinions and behaviours different from their own. People of high uncertainty avoidance have a strong need to control environment, situations and events. Users with high uncertainty avoidance culture would hesitate to choose uncertain situations. High uncertainty avoiders are cautious in choosing ISF's services; they do not make quick decisions. As a result of their risk-aversive decisions, such users are likely to perceive low service quality of the ISF's services. Such users would use tangibles as a surrogate of service quality because tangibles are visible evidence. However, this might not hold true in ISF's services that involve a major intangible component. Thus:

Hypothesis 2a: High uncertainty avoidance users have low ISF's service quality perceptions.

Hypothesis 2b: Low uncertainty avoidance users have high ISF's service quality perceptions.

Individualism (IDV) pertains to "societies in which the ties between individuals are loose: everyone is expected to look after himself or herself and his or her immediate family," and collectivism, its opposite, pertains to "societies in which people from birth onwards are integrated into strong, cohesive in groups, which throughout people's lifetime continue to protect them in exchange for unquestioning loyalty" (Hofstede, 1991, p.51). Individualistic people prefer to act as individuals rather than as members of groups. In an individualistic society, where self-concept and free will or freedom prevail, people develop a great sense of autonomy and personal achievement as opposed to a sense of collectivism and importance of social and security needs (Hofstede, 1980). Individualistic people emphasise job specialisation, individual rewards, competitive climate and individual family independence. Low individualism users emphasise the 'we' (both the users and the ISF) rather than the 'I' (the users) because they stress interdependence in human relations. Such users would likely tolerate poor services of the ISF because they do not break the relationships between them and the ISF. Therefore, low individualism users do not have high level of service quality perceptions. When individualism is low, service users may not openly express their attitudes and beliefs about ISF service quality. ISF service quality assessments will be influenced by group opinion.

Hypothesis 3a: Low individualism users have low ISF's service quality perceptions.

Hypothesis 3b: High individualism users have high ISF's service quality perceptions. 
Masculinity (MAS) represents "the dominant sex role pattern in the vast majority of both traditional and modern societies" (Hofstede, 1991, p.277). In high-masculinity societies, social gender roles are clearly distinct: men are supposed to be assertive, tough and focused on material success, whereas women are supposed to be more modest, tender and concerned with the quality of life (Hofstede, 1991). Jordan traditionally prohibits women from some jobs and from working during night hours, but IT is one occupational area exempted from this (Majcher-Teleon and Slimène, 2009). In cultures with a high degree of masculinity, the relative importance of the service quality dimensions is different depending on whether the service is provided by a male or female service employee. In such a culture, users may expect a male service employee to be professional, more reliable and more responsive than a female one. A female service employee is expected to be more empathic than a male one. On the other hand, in more feminine cultures, where social gender roles overlap (Hofstede, 1991), whether the service employee is a male or a female will not make any difference in the end-user's perception of the importance of the different service quality dimensions.

Hypothesis 4a: High-masculinity users have low ISF's service quality perceptions if they were served by a female support employee.

LTO is the extent to which a society exhibits a pragmatic future-oriented perspective (fostering virtues like perseverance and thrift) rather than a conventional historic or short-term point of view (Hofstede, 1991, p.165). In cultures with a LTO, long-term relationships with the ISF are expected. In these cultures, reliability, responsiveness and empathy are important, as a result of close relationships with the ISF. Assurance and tangibles will be less important in these cultures. In such cultures, relationships with the ISF are expected to last, so assurance is not so critical.

Hypothesis 5a: Low LTO users have low ISF's service quality perceptions.

In Hofstede's original typology, Jordan is diametrically opposite to Australia on each of the four original dimensions, whilst both are low on LTO. For Jordan, the original numerical scores were inferred, since Hofstede only sampled five Arab countries and then generalised to include Jordan, but have not been radically challenged over the many subsequent studies by individual researchers, nor globally, for example, by the World Values Survey (http://www.worldvaluessurvey.org). A recent 'replication' of Hofstede's study (Alkailani et al, 2012) conducted in Jordan indicated that the dimensions of masculinity and individualism scores are indeed very similar to other Arab countries, though Jordan was relatively lower on the other two dimensions. The authors attributed this to a young and educated workforce, who is routinely consulted and unafraid to "disagree with their bosses". On the other hand, another study (Sabri, 2012), this time with managers in Jordan, DID reaffirm their high uncertainty avoidance and high power distance scores. Specific recent figures for both countries (Hofstede Centre, n.d.) affirm that the original pattern distinguishing relative value dominance remains the case. On the 'LTO' dimension, Minkov and Hofstede (2012) found Jordan to have a low rating, though they did not consider the Australian data in that study. Since, however, Australia rated low (31) in the original study, and Jordan's score on LTO is reported as being 30 (Hofstede Centre, n.d.), for the purposes of the present study both are considered low. Table 3 summarises the overall differences between the Jordanian and the Australian cultures based on Hofstede's studies. ${ }^{4}$ 
Table 3 Jordanian and Australian cultures based on Hofstede's studies

\begin{tabular}{lcc}
\hline \multicolumn{1}{c}{ Dimension } & Jordan & Australia \\
\hline Power distance & High & Low \\
Individualism & Low & High \\
Masculinity & High & Low \\
Uncertainty avoidance & High & Low \\
Long-term orientation & Low & Low \\
\hline
\end{tabular}

\section{Research approach and methodology}

\subsection{Measurement}

The IS ZOT SERVQUAL instrument developed by Kettinger and Lee (2005) was appropriate for this study. The IS ZOT SERVQUAL contains measures for desired, adequate and perceived service quality levels, and identifies 18 commonly applicable question items. The survey length of the IS ZOT SERVQUAL, however, adds some complexity when compared to a single point (perception only) measure. Kettinger and Lee (2005, p.614) have stated that "in cases where brevity, cost, or predictive validity concerns demand, the seemingly less clinical perception-only (SERVPERF) measure might be a better option". Hence, in this study, the 18-item SERVPREF measure was used to evaluate users' perceptions of the ISF's service quality.

\subsection{Sampling and data collection}

Cross-cultural research is challenging due to sources of bias, such as construct equivalence, familiarity with method and item translation (van de Vijver and Tanzer, 1997). Steps were taken to minimise these. Firstly, the data were collected from demographically equivalent business IT students at two well-established public universities in Jordan, and at a well-established public university in Australia. These student subjects were used because they constitute a homogeneous group from an occupational stage of life cycle viewpoint. Their (information systems) education implies their familiarity with the concepts at question and they also have frequent relationships with the central university ISF. They usually contact the ISF for a range of services, such as connecting to the university-wide network, enrolment support, support of computer laboratories, consulting, training and normal help desk assistance. Along with both groups' general familiarity with the questionnaire and rating method from e.g. student surveys, this means they will have informed perceptions of service quality.

The data collection in Jordan involved translation effort, as the country's official language is Arabic. Several translation techniques are reported in the literature (e.g. Brislin, 1970; Brislin, 1986; Hansen, 1987; Samaddar and Kadiyala, 2006). Brislin's (1986) translation guidelines (which recommend, inter alia, short sentences, active voice, avoidance of pronouns, colloquialisms, metaphors and possessive forms) were thought to be the most appropriate for the context of this study. These guidelines are considered best 
practice, and the effort was aided by the universality of both IT terms and concepts, and because the first author speaks native Jordanian Arabic. This was considered to obviate the need for independent back translation.

\subsection{Participants}

Two anonymous, self-administered, written survey instruments were distributed to (1) 265 undergraduate IT students in two Jordanian universities (221 usable responses were collected, which is $83.3 \%$ response rate) and (2) 246 undergraduate business students in the Australian university (174 usable responses were collected, a response rate of $78.7 \%$ ). Students were told that participation in the study was voluntary.

The survey was divided into three sections. In the first section, respondents were asked some demographic questions for classification purposes. In the second section, respondents were asked to indicate the frequency of their contacts with their ISF and if they were familiar with their ISF services. The Jordanian survey instrument included one additional question to distinguish those respondents whom female service staff frequently served. ${ }^{5}$

Only respondents who were familiar with various ISF services and frequently used these services were considered in the data analysis of this study. The third section measures their perceived ISF's service quality (SERVPREF). With an option for 'no opinion', a seven-point Likert scale was used to measure SERVPREF with a statement for each of the 18 items, from 1 (strongly disagree) to 7 (strongly agree).

\section{Research findings}

The first author was familiar with both countries and felt that similar segments were represented. Analysis of the demographic data affirmed that the non-random samples did not differ significantly in age, gender or educational level. In the Jordanian case, no difference in perceptions was found between those served by male or female IT staff so the data were pooled.

The four dimensions of the SERVPREF scale were highly reliable. By using the pooled data and Leung and Bond's (1989) standardising technique for cross-cultural comparisons, average Cronbach's $\alpha$ values of $0.83,0.88,0.82$ and 0.86 , respectively, were found for the dimensions of responsiveness, reliability, rapport, and tangibles. Table 4 summarises Cronbach's $\alpha$ (reliability) values for the two countries.

Table 4 Summary of Cronbach's $\alpha$ (reliability) values for the two samples

\begin{tabular}{lccc}
\hline \multicolumn{1}{c}{ Dimension } & $\begin{array}{c}\text { Reliability (Jordanian } \\
\text { sample) }(n=221)\end{array}$ & $\begin{array}{c}\text { Reliability (Australian } \\
\text { sample })(n=174)\end{array}$ & $\begin{array}{c}\text { Average reliability } \\
\text { (both samples) }\end{array}$ \\
\hline Responsiveness & 0.82 & 0.83 & 0.83 \\
Reliability & 0.88 & 0.87 & 0.88 \\
Rapport & 0.79 & 0.85 & 0.82 \\
Tangibles & 0.87 & 0.85 & 0.86 \\
\hline
\end{tabular}


Next, the mean and the standard deviation were calculated for both samples. With an option for 'no opinion', a seven-point Likert scale was used to measure SERVPREF with a statement for each of the 18 items, from 1 (strongly disagree) to 7 (strongly agree). The Australian sample showed consistently greater means and variance on all items. Indeed, while the modal response of the Australian respondents on all items was 'neutral' or 'moderately agree', the modal response of Jordanian respondents was 'moderately disagree' or 'disagree'. Table 5 represents the summary results.

Table 5 Differences in the perceived ISF's service quality in the two samples

\begin{tabular}{|c|c|c|c|c|c|}
\hline \multirow[t]{2}{*}{ Dimension } & \multirow[t]{2}{*}{ Measures } & \multicolumn{2}{|c|}{$\begin{array}{l}\text { Jordanian sample } \\
\quad(n=221)\end{array}$} & \multicolumn{2}{|c|}{$\begin{array}{l}\text { Australian sample } \\
\quad(n=174)\end{array}$} \\
\hline & & Mean & $S D$ & Mean & $S D$ \\
\hline \multirow[b]{2}{*}{ Responsiveness } & Willingness to help users & 3.45 & 1.55 & 5.62 & 2.34 \\
\hline & $\begin{array}{l}\text { Readiness to respond to user's } \\
\text { requests }\end{array}$ & 3.51 & 1.65 & 5.89 & 2.45 \\
\hline \multirow{6}{*}{ Reliability } & Providing services as promised & 2.98 & 2.02 & 4.54 & 1.21 \\
\hline & $\begin{array}{l}\text { Dependability in handling } \\
\text { user's service problems }\end{array}$ & 3.51 & 2.33 & 5.21 & 2.02 \\
\hline & $\begin{array}{l}\text { Performing service right the } \\
\text { first time }\end{array}$ & 2.14 & 1.95 & 4.87 & 2.09 \\
\hline & $\begin{array}{l}\text { Providing services at the } \\
\text { promised time }\end{array}$ & 2.68 & 1.79 & 4.09 & 2.48 \\
\hline & $\begin{array}{l}\text { Maintaining the reliable } \\
\text { technology and system }\end{array}$ & 3.25 & 2.07 & 5.65 & 2.21 \\
\hline & Prompt service to users & 2.21 & 1.01 & 4.36 & 2.06 \\
\hline \multirow{7}{*}{ Rapport } & $\begin{array}{l}\text { Making users feel safer in } \\
\text { computer transactions }\end{array}$ & 3.45 & 1.93 & 5.48 & 2.87 \\
\hline & $\begin{array}{l}\text { IS employees who are } \\
\text { consistently courteous }\end{array}$ & 2.98 & 1.13 & 4.56 & 1.25 \\
\hline & $\begin{array}{l}\text { IS employees who have the } \\
\text { knowledge to answer users' } \\
\text { questions }\end{array}$ & 2.05 & 1.29 & 4.63 & 1.66 \\
\hline & $\begin{array}{l}\text { Giving users individual } \\
\text { attention }\end{array}$ & 3.69 & 2.01 & 5.84 & 2.04 \\
\hline & $\begin{array}{l}\text { IS employees who deal with } \\
\text { users in a caring fashion }\end{array}$ & 3.16 & 1.98 & 5.36 & 2.59 \\
\hline & $\begin{array}{l}\text { Having the user's best interest } \\
\text { at heart }\end{array}$ & 2.36 & 1.48 & 4.73 & 1.50 \\
\hline & $\begin{array}{l}\text { IS employees who understand } \\
\text { the needs of users }\end{array}$ & 3.54 & 2.55 & 5.33 & 2.21 \\
\hline \multirow{3}{*}{ Tangibles } & Visually appealing facilities & 3.45 & 2.47 & 5.02 & 2.01 \\
\hline & $\begin{array}{l}\text { IS employees who appear } \\
\text { professional }\end{array}$ & 3.21 & 2.16 & 4.56 & 2.78 \\
\hline & $\begin{array}{l}\text { Useful support materials (such } \\
\text { as documentation, training, } \\
\text { videos, etc.) }\end{array}$ & 1.55 & 1.02 & 5.47 & 2.34 \\
\hline
\end{tabular}


Variance and $t$-tests analyses were also carried out to test Hypotheses $1 \mathrm{a}, 1 \mathrm{~b}, 2 \mathrm{a}, 2 \mathrm{~b}, 3 \mathrm{a}$ and $3 \mathrm{~b}$. The results are summarised in Table 6 . As discussed earlier, while the Jordanian respondents have high power distance, high uncertainty avoidance and low individualism, the Australian respondents have the opposite culture characteristics. Overall, the Jordanian sample had lower ISF's service quality perceptions than the Australian sample in all SERVPREF's dimensions. The overall ISF's service quality perceptions were therefore lower for the Jordanian sample than for the Australian sample (mean 2.95 vs. 5.07). All of those differences were significant at the 0.05 level, providing empirical support for Hypotheses 1a, 1b, 2a, 2b, 3a and 3b. The overall ISF's service quality perceptions for the Jordanian sample (mean 2.95) also provide empirical support for Hypotheses $4 \mathrm{a}$ and $5 \mathrm{a}$.

Table 6 Hypotheses 1a, 1b, 2a, 2b, 3a and 3b testing results

\begin{tabular}{lccccc}
\hline \multirow{2}{*}{ Description } & Responsiveness & Reliability & Rapport & Tangibles & $\begin{array}{c}\text { Overall } \\
\text { SERVPREF }\end{array}$ \\
\cline { 2 - 6 } & 3.48 & 2.80 & 3.03 & 2.74 & 2.95 \\
\hline Jordanian sample & 5.76 & 4.79 & 5.13 & 5.01 & 5.07 \\
\hline Australian sample & Yes & Yes & Yes & Yes & Yes \\
\hline $\begin{array}{l}\text { Difference significant } \\
\text { at the 0.05 level? }\end{array}$ & & &
\end{tabular}

Considered individually, Hypothesis 1 was that service quality perceptions would vary in the opposite direction to power distance score. The high power distance score of Jordan was associated with significantly lower perceptions $(p<0.05)$ on each of the SERVPREF dimensions and vice versa for Australia. Similarly, with Hypothesis 2, higher uncertainty avoidance (Jordan) was also associated with lower perceptions $(p<0.05)$. Hypothesis 3 suggested individualism was positively associated with the level of perceptions, and the higher score for Australia on this dimension was indeed associated with a significantly higher overall score $(p<0.05)$ for perception level. Hypothesis 4 was predicated on the different gender perceptions in a masculine culture, but analyses suggested there was no difference in service quality perceptions between male and female staff. A closer look at the data confirmed that the rapport dimensions scored more highly for females than for males, but overall the general professionalism perceptions were the same for both genders, as was the case in Australia. Finally, Hypothesis 5 considered that low LTO scores would be associated with lower perceptions. This was confirmed in the case of Jordan but not with Australia, where a low LTO score was associated with relatively higher service quality perceptions. This may mean the dimension is not especially relevant to student cohorts, who have a limited time relationship with the particular ISF in their university, or that Australian students expect the service to be of high quality regardless. Overall, however, the hypotheses were supported, and detailed analysis for these is presented in Table 7. 
Table 7 Detailed $t$-test and $p$-values results

\begin{tabular}{|c|c|c|c|c|c|c|}
\hline \multirow[t]{2}{*}{ Dimension } & \multirow[t]{2}{*}{ Measures } & \multicolumn{4}{|c|}{ 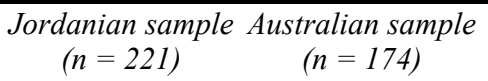 } & \multirow[t]{2}{*}{ t-test, $d f$ and $p$-value } \\
\hline & & Mean & $S D$ & Mean & $S D$ & \\
\hline \multirow[b]{2}{*}{ Responsiveness } & $\begin{array}{l}\text { Willingness to help } \\
\text { users }\end{array}$ & 3.45 & 1.55 & 5.62 & 2.34 & $\begin{array}{c}t=11.0487 \\
d f=393, p<.0001\end{array}$ \\
\hline & $\begin{array}{l}\text { Readiness to } \\
\text { respond to user's } \\
\text { requests }\end{array}$ & 3.51 & 1.65 & 5.89 & 2.45 & $\begin{array}{c}t=11.5046 \\
d f=393, p<.0001\end{array}$ \\
\hline \multirow{6}{*}{ Reliability } & $\begin{array}{l}\text { Providing services } \\
\text { as promised }\end{array}$ & 2.98 & 2.02 & 4.54 & 1.21 & $\begin{array}{c}t=8.4752 \\
d f=393, p<.0001\end{array}$ \\
\hline & $\begin{array}{l}\text { Dependability in } \\
\text { handling user's } \\
\text { service problems }\end{array}$ & 3.51 & 2.33 & 5.21 & 2.02 & $\begin{array}{c}t=7.6280 \\
d f=393, p<.0001\end{array}$ \\
\hline & $\begin{array}{l}\text { Performing service } \\
\text { right the first time }\end{array}$ & 2.14 & 1.95 & 4.87 & 2.09 & $\begin{array}{c}t=13.3822 \\
d f=393, p<.0001\end{array}$ \\
\hline & $\begin{array}{l}\text { Providing services } \\
\text { at the promised time }\end{array}$ & 2.68 & 1.79 & 4.09 & 2.48 & $\begin{array}{c}t=6.5574 \\
d f=393, p<.0001\end{array}$ \\
\hline & $\begin{array}{l}\text { Maintaining the } \\
\text { reliable technology } \\
\text { and system }\end{array}$ & 3.25 & 2.07 & 5.65 & 2.21 & $\begin{array}{c}t=10.6867 \\
d f=393, p<.0001\end{array}$ \\
\hline & $\begin{array}{l}\text { Prompt service to } \\
\text { users }\end{array}$ & 2.21 & 1.01 & 4.36 & 2.06 & $\begin{array}{c}t=13.5830 \\
d f=393, p<.0001\end{array}$ \\
\hline \multirow{7}{*}{ Rapport } & $\begin{array}{l}\text { Making users feel } \\
\text { safer in computer } \\
\text { transactions }\end{array}$ & 3.45 & 1.93 & 5.48 & 2.87 & $\begin{array}{c}t=8.3812 \\
d f=393, p<.0001\end{array}$ \\
\hline & $\begin{array}{l}\text { IS employees who } \\
\text { are consistently } \\
\text { courteous }\end{array}$ & 2.98 & 1.13 & 4.56 & 1.25 & $\begin{array}{c}t=13.1631 \\
d f=393, p<.0001\end{array}$ \\
\hline & $\begin{array}{l}\text { IS employees who } \\
\text { have the knowledge } \\
\text { to answer users' } \\
\text { questions }\end{array}$ & 2.05 & 1.29 & 4.63 & 1.66 & $\begin{array}{c}t=17.3828 \\
d f=393, p<.0001\end{array}$ \\
\hline & $\begin{array}{l}\text { Giving users } \\
\text { individual attention }\end{array}$ & 3.69 & 2.01 & 5.84 & 2.04 & $\begin{array}{c}t=10.4848 \\
d f=393, p<.0001\end{array}$ \\
\hline & $\begin{array}{l}\text { IS employees who } \\
\text { deal with users in a } \\
\text { caring fashion }\end{array}$ & 3.16 & 1.98 & 5.36 & 2.59 & $\begin{array}{c}t=9.5674 \\
d f=393, p<.0001\end{array}$ \\
\hline & $\begin{array}{l}\text { Having the user's } \\
\text { best interest at heart }\end{array}$ & 2.36 & 1.48 & 4.73 & 1.50 & $\begin{array}{c}t=15.7063 \\
d f=393, p<.0001\end{array}$ \\
\hline & $\begin{array}{l}\text { IS employees who } \\
\text { understand the } \\
\text { needs of users }\end{array}$ & 3.54 & 2.55 & 5.33 & 2.21 & $\begin{array}{c}t=7.3398 \\
d f=393, p<.0001\end{array}$ \\
\hline \multirow{3}{*}{ Tangibles } & $\begin{array}{l}\text { Visually appealing } \\
\text { facilities }\end{array}$ & 3.45 & 2.47 & 5.02 & 2.01 & $\begin{array}{c}t=7.3398 \\
d f=393, p<.0001\end{array}$ \\
\hline & $\begin{array}{l}\text { IS employees who } \\
\text { appear professional }\end{array}$ & 3.21 & 2.16 & 4.56 & 2.78 & $\begin{array}{c}t=5.4316 \\
d f=393, p<.0001\end{array}$ \\
\hline & $\begin{array}{l}\text { Useful support } \\
\text { materials (such as } \\
\text { documentation, } \\
\text { training and videos) }\end{array}$ & 1.55 & 1.02 & 5.47 & 2.34 & $\begin{array}{c}t=22.3573 \\
d f=393, p<.0001\end{array}$ \\
\hline
\end{tabular}




\section{Summary, implications and limitations}

In this paper, we hypothesised and tested the influences of culture on users' service quality perceptions and found strong empirical support for all of the study's hypotheses. This paper has reported a clear effect of culture on perceptions of IS service quality, indicating that, associated directly with their cultural characteristics, users vary in both their overall service quality perceptions and their perceptions on each of ZOT's four dimensions of service quality. The dominant cultural values of high power distance, uncertainty avoidance, masculinity and low individualism that characterise Jordanian culture contrast directly with Australia's profile, and was associated with significantly lower perceptions of service quality. Our suggestion is that this results from the Jordanian culture's tolerance of power inequalities and greater risk aversion, and its collectivist orientation means lower quality services would be tolerated more to preserve social bonds.

Having shown that ISF's service quality dimensions vary from one culture to another, the findings of this study may provide useful insights into how organisations should deal with different cultural groups. Whilst the modal responses for the Australian respondents were in the upper part of the Likert scales, the Jordanians were on the lower part. The Jordanian respondents were culturally more homogeneous, since Australia, despite its melting pot society, has a large number of temporary international students, and this was perhaps reflected in the greater standard deviations seen for the Australian group. As the Australian perceptions were higher on all SERVPREF items, this result implies that, regardless of background or relationship length with the ISF, a higher perception of service quality applies in Australian culture. The collectivist culture of Jordan, where loyalty to the group is more important than breaking the interdependent social relationships with the ISF, implies that a lower perception will be tolerated in ways unlikely to be accepted in highly individualistic cultures such as Australia.

This study is a first step in understanding cultural influences on ISF's service quality and hence has some limitations, including the following: firstly, the authors tested the hypotheses in the context of only one ISF at different universities; hence, the hypotheses must be tested in other types of ISFs to identify any wider differences. The relatively higher ratings for service quality in the banking sector found by Mohammad and Alhamadani (2011) may reflect a higher maturity in the private than in public sector organisations such as universities. The question arises that if service quality is in fact poorer, lower ratings may represent correct perceptions, but there was no direct evidence that this was the case, and for a diagnosis of this, the full SERVQUAL instrument could be usefully applied. Relatedly, the structure of universities and their ISFs differ among countries, and this may affect users' perceptions. Another limitation was that the newer dimensions of Hofstede's typology should be used in future studies as validated figures emerge for these. Treating regions with diverse countries as homogenous has already been noted as a limitation of Hofstede's original study. Intra-regional comparisons with reliable and appropriate instruments will be helpful in contextualising future research results, and instruments that recognise the cultural diversity within the Arab world are beginning to emerge. Future studies should also employ diverse respondents from several countries, as this paper used similar respondents from only two countries and at a point in time when a younger generation is beginning to emerge with possibly different values in play. Finally, despite wide acceptance, validity and reliability of the SERVPREF scale, 
the author recommends future researchers to retest the study's hypotheses using different measures of service quality perceptions, and supplement with qualitative data to obtain a rounded picture of the cultural influences on service quality.

\section{References}

Alkailani, M. Azzam, I.A. and Athamneh, A.B. (2012) 'Replicating Hofstede in Jordan: ungeneralized, reevaluating the Jordanian culture', International Business Research, Vol. 5, No. 4, pp.71-80.

Al-Tamimi, H.A. and Al-Amiri, A. (2003) 'Analyzing service quality in the UAE Islamic banks', Journal of Financial Service Marketing, Vol. 8, No. 2, pp.119-132.

Benedict, R. (1946) The Chrysanthemum and the Sword: Patterns of Japanese Culture, Houghton Mifflin, Boston, MA.

Brislin, R.W. (1970) 'Back-translation for cross-cultural research', Journal of Cross-Cultural Psychology, Vol. 1, pp.185-216.

Brislin, R.W. (1986) 'The wording and translation of research instruments', in Lonner, W. and Berry, W. (Eds): Field Method in Cross-culture Research, Sage, Beverly Hills, CA, pp.137-164.

Buttle, F. (1996) 'SERVQUAL: review, critique, research agenda', European Journal of Marketing, Vol. 30, No. 1, pp.8-31.

Carlson, W. and McNurlin, B. (1992) 'Basic principles for measuring IT value', I/S Analyzer, Vol. 30, No. 10, pp.1-16.

Carr, L. (2002) 'A psychometric evaluation of the expectations, perceptions, and difference-scores generated by the IS-adapted SERVQUAL instrument', Decision Sciences, Vol. 33, No. 2, pp.281-296.

Carrillat, F.A., Jaramillo, F. and Mulki, J.P. (2007) 'The validity of the SERVQUAL and SERVPERF scales: a meta-analytic view of 17 years of research across five continents', International Journal of Service Industry Management, Vol. 18, No. 5, pp.472-490.

Chang, J. and King, W. (2005) 'Measuring the performance of information systems: a functional scorecard', Journal of Management Information Systems, Vol. 22, No. 1, pp.85-115.

Cronin, J.J. and Taylor, S.A. (1992) 'Measuring service quality: a reexamination and extension', Journal of Marketing, Vol. 6, pp.55-68.

Donthu, N. and Boonghee, Y. (1998) 'Cultural influences on service quality expectations', Journal of Service Research, Vol. 1, No. 2, pp.178-186.

Edvardsson, B. and Gustavsson, B. (1988) 'Quality in services and quality in service organizations: a model for quality assessment', in Brown, S., Gummesson, E., Edvardsson, B. and Gustavsson, B. (Eds): Service Quality, Multidisciplinary and Multinational Perspectives, Lexington Books, Lexington, MA, pp.319-340.

Espinoza, M.M. (1999) 'Assessing the cross-cultural applicability of a service quality measure: a comparative study between Quebec and Peru', International Journal of Service Industry Management, Vol. 10, No. 5, pp.449-468.

Fisk, R., Brown, S. and Bitner, M. (1993) 'Tracking the evolution of the services marketing literature', Journal of Retailing, Vol. 69, No. 1, pp.61-103.

Hall, E.T. (1976) Beyond Culture, Anchor Press/Doubleday, Garden City, NY.

Hansen, C. (1987) 'Cross-cultural research on vocational interests', Measurement and Evaluation in Counseling and Development, Vol. 19, No. 4, pp.163-176.

Ho, H., Raman, S. and Watson, T. (1989) 'Group decision support systems: the cultural factors', Paper presented at The 10th International Conference on Information Systems, Boston, MA. 
Hofstede Centre (n.d.) Cultural Survey Report. Available online at: http://geert-hofstede.com/ tl_files/Cultural\%20Survey\%20Report.pdf (accessed on 2 February 2014).

Hofstede, G. (1980) Culture's Consequences: International Differences in Work-Related Values, Sage, Beverly Hills, CA.

Hofstede, G. (1991) Cultures and Organizations: Software of the Mind, McGraw-Hill, London.

Hofstede, G. (1994) 'Management scientists are human', Management Science, Vol. 40, No. 1, pp.4-13.

House, R.J., Hanges, P.J., Javidan, M., Dorfman, P.W. and Gupta, V. (Eds) (2004) Culture, Leadership, and Organizations: The Globe Study of 62 Societies, Sage, Thousand Oaks, CA.

Jabnoun, N. and Khalifa, A. (2005) 'A customized measure of service quality in the UAE', Managing Service Quality, Vol. 15, No. 4, pp.374-388.

Jain, S.K. and Gupta, G. (2004) 'Measuring service quality: SERVQUAL vs. SERVPERF scales', Vikalpa, Vol. 29, No. 2.

Jayawardhena, C. (2004) 'Measurement of service quality in internet banking: the development of an instrument', Journal of Marketing Management, Vol. 20, Nos. 1-2, pp.185-207.

Jiang, J.J., Klein, G. and Carr, C. (2002) 'Measuring information system service quality: SERVQUAL from the other side', MIS Quarterly, Vol. 26, No. 2, pp.145-166.

Kettinger, W. and Lee, C. (1994) 'Perceived service quality and user satisfaction with the information services function', Decision Sciences, Vol. 25, Nos. 5-6, pp.737-766.

Kettinger, W. and Lee, C. (1997) 'Pragmatic perspectives on the measurement of information systems service quality', MIS Quarterly, Vol. 21, No. 2, pp.223-241.

Kettinger, W. and Lee, C. (2005) 'Zones of tolerance: alternative scales for measuring information systems service quality', MIS Quarterly, Vol. 29, No. 4, pp.607-623.

Kettinger, W., Lee, C. and Lee, S. (1995) 'Global measures of information service quality: a crossnational study', Decisions Sciences, Vol. 26, No. 5, pp.569-588.

King, J. and Sethi, V. (1993) 'Developing transnational information systems: a case study', Information and Management, Vol. 21, No. 1, pp.53-59.

Kroeber, A.L. and Kluckhohn, Cl. (1952) Culture: A Critical Review of Concepts and Definitions, Vintage books, New York.

Leung, K. and Bond, M. (1989) 'On the empirical identification of dimensions for cross-cultural comparisons', Journal of Cross-Cultural Psychology, Vol. 20, pp.133-151.

Li, Y., Tan, K. and Xie, M. (2003) 'Factor analysis of service quality dimension shifts in the information age', Computing Surveys, Vol. 10, No. 1, pp.19-34.

Majcher-Teleon, A. and Slimène, O.B. (2009) Women and Work in Jordan: Case Study of Tourism and ICT Sectors, European Training Foundation (ETF), Turin, Italy.

Malhotra, K., Ulgado, M., Agarwal, J. and Baalbaki, B. (1994) 'International services marketing, a comparative evaluation of the dimensions of service quality between developed and developing countries', International Marketing Review, Vol. 11, No. 2, pp.5-15.

Markus, H.R. and Kitayama, S. (1991) 'Culture and the self: implications for cognition, emotion, and motivation', Psychological Review, Vol. 98, No. 2, pp.224-253.

Mattila, S. (1990) 'The role of culture in the service evaluation process', Journal of Service Research, Vol. 1, No. 3, pp.250-261.

Minkov, M. and Hofstede, G. (2012) 'Hofstede's fifth dimension: new evidence from the world values survey', Journal of Cross-Cultural Psychology, Vol. 43, No. 1, pp.3-14.

Mohammad, A.A.S. and Alhamadani, S.Y.M. (2011) 'Service quality perspective and customer satisfaction in commercial banking in Jordan', Middle Eastern Finance and Economics, Vol. 14, pp.60-72.

Munkvold, R. (2003) 'End user support usage', in Gordon, S. (Ed.): Computing Information Technology: The Human Side, IRM Press, Hershey, PA. 
Nelson, R., Weiss, R. and Yamazaki, K. (1992) 'Information resource management within multinational corporation', International Information Systems, Vol. 1, No. 4, pp.57-88.

Parasuraman, A., Berry, L. and Zeithaml, V. (1991) 'Refinement and reassessment of service quality', Journal of Retailing, Vol. 64, No. 1, pp.12-40.

Parasuraman, A., Zeithaml, V. and Berry, L. (1988) 'SEVQUAL: a multiple-item scale for measuring consumer perceptions of service quality', Journal of Retailing, Vol. 64, No. 1, pp. $12-40$.

Parasuraman, A., Zeithaml, V.A. and Berry, L. (1993) 'More on improving the measurement of service quality', Journal of Retailing, Vol. 69, No. 1, pp.140-147.

Petter, S., DeLone, W. and McLean, E. (2008) 'Measuring information systems success: models, dimensions, measures, and interrelationships', European Journal of Information Systems, Vol. 17, No. 3, pp.236-263.

Pitt, F., Watson, T. and Kavan, C.B. (1995) 'Service quality: a measure of information systems effectiveness', MIS Quarterly, Vol. 19, No. 2, pp.173-185.

Pitt, F., Watson, R. and Kavan, C.B. (1997) 'Measuring information service quality: concerns for a complete canvas', MIS Quarterly, Vol. 21, No. 2, pp.209-222.

Rabaa'i, A. (2009) 'The impact of organizational culture on ERP systems implementation: lessons from Jordan', Paper presented at The 13th Pacific Asia Conference on Information Systems (PACIS), Hyderabad, India

Robey, D., and Rodriguez-Diaz, A. (1989) 'The organizational and cultural content of systems implementation: case experience in Latin America', Information and Management, Vol. 17, No. 4, pp.229-239.

Sabri, H.A. (2012) 'Re-examination of Hofstede's work value orientations on perceived leadership styles in Jordan', International Journal of Commerce and Management, Vol. 22, No. 3, pp.202-218.

Samaddar, S. and Kadiyala, S. (2006) 'Information systems outsourcing: replicating an existing framework in a different cultural context', Journal of Operations Management, Vol. 24, No. 6, pp.910-931.

Saunders, C.S., and Jones, J.W. (1992) 'Measuring performance of the information systems function', Journal of Management Information Systems, Vol. 8, No. 4, pp.63-82.

Shaw, N., DeLone, W. and Niederman, F. (2002) 'Sources of dissatisfaction in end user support: an empirical study', The DATA BASE for Advances in Information Systems, Vol. 33, No. 2, pp.41-56.

Trompenaars, F. and Hampden-Turner, C (1997) Riding the Waves of Culture: Understanding Diversity in Global Business, Nicholas Brealey Publishing, London.

Van de Vijver, F.J.R. and Tanzer, N.K. (1997) 'Bias and equivalence in cross-cultural assessment: an overview', European Review of Applied Psychology, Vol. 47, No. 4, pp.263-280.

Van Dyke, T.P., Kappelman, L.A. and Prybutok, V.R. (1997) 'Measuring information systems service quality: concerns on the use of the SERVQUAL questionnaire', MIS Quarterly, Vol. 21, No. 2, pp.195-208.

Van Dyke, T.P, Prybutok, V.R. and Kappelman, L.A. (1999) 'Cautions on the use of the SERVQUAL measure to assess the quality of information systems services', Decision Sciences, Vol. 30, No. 3, pp.877-891.

Velsen, L.S.V., Steehouder, M.F. and Jong, M.D.T.D. (2007) 'Evaluation of user support: factors that affect user satisfaction with helpdesks and helplines', IEEE Transactions on Professional Communication, Vol. 50, No. 3, pp.219-231.

Wang, Y. and Tang, T. (2003) 'Assessing customer perceptions of web sites service quality in digital marketing environments', Journal of End User Computing, Vol. 15, No. 3, pp.14-31.

Watson, R., Pitt, L. and Kavan, B. (1998) 'Measuring information systems service quality: lessons from two longitudinal case studies', MIS Quarterly, Vol. 22, No. 1, pp.61-79. 
Yoo, B., Donthu, N. and Lenartowicz, T. (2011) 'Measuring Hofstede's five dimensions of cultural values at the individual level: development and validation of CVSCALE', Journal of International Consumer Marketing, Vol. 23, Nos. 3-4, pp.193-210.

Zmud, W. (1984) 'Design alternatives for organizing information systems activities', MIS Quarterly, Vol. 8, No. 2, pp.79-93.

\section{Notes}

1 SERVQUAL is also known as RATER, an acronym based on the five dimensions shown in Table 1 as the instrument was refined.

2 This was an attempt to distinguish specifically Eastern (Confucian) modes from Western ways of thinking, which could not be determined from the original data, and brought a greater rapprochement with other mainstream conceptualisations that recognised different cultural understandings of time. A sixth, indulgence vs. restraint, has also been recently added but was not included here.

3 The GLOBE study of House et al. (2004) identified nine dimensions empirically from approximately 17,000 middle managers in 62 countries. These included several dimensions similar to those of Hofstede, but were more focused towards investigating how organisational leadership effectiveness was culturally contingent.

4 Note that the differences in this table are based on the two countries' cultures.

5 As noted in Section 3, this was to establish whether the high MAS value in Jordanian culture was associated with a difference in service perceptions (i.e. reliability vs. rapport). When Jordanian respondents with more experience of being served by women were compared to those with less experience of being served by women, no significant differences emerged in their perceptions, so were pooled for the comparative analysis. 